Page 1 of

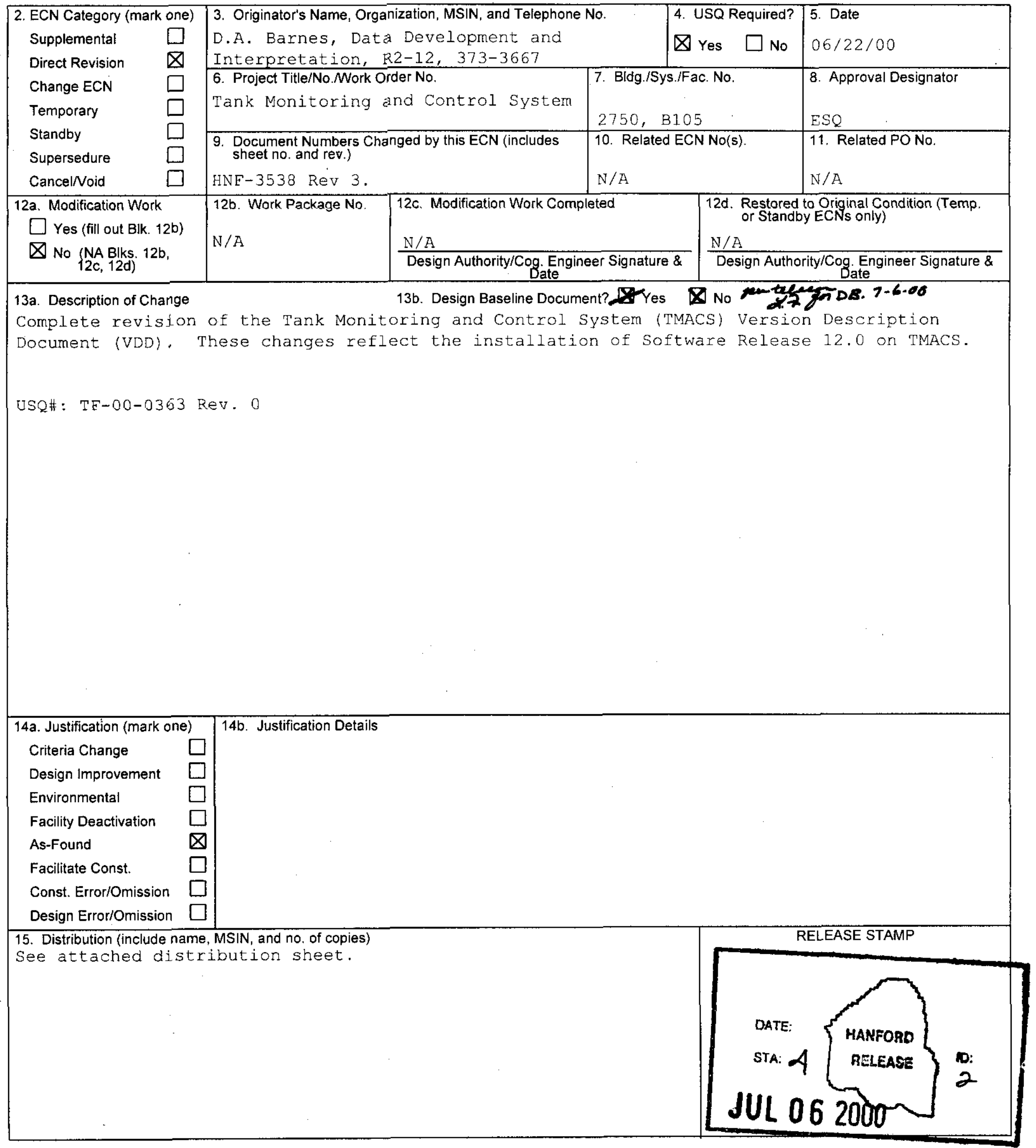




\section{ENGINEERING CHANGE NOTICE}

\begin{tabular}{l|l} 
Page 2 of 2 & $\begin{array}{l}\text { 1. ECN (use no. from pg. 1) } \\
\text { ECN } 656000\end{array}$ \\
If STION & $\begin{array}{l}\text { 18. Schedule Impact (days) } \\
\text { Improvement } \square\end{array}$ \\
\hline
\end{tabular}

16. Design Verification Required

$\square$ Yes

$\bigotimes$ No
17. Cost Impact

ENGINEERING

Additional $\square$ \$

Savings $\square \$$

\section{CONSTRUCTION}

Additional $\square$ \$

Savings $\square \$$

Delay

19. Change Impact Review: Indicate the related documents (other than the engineering documents identified on Side 1) that will be affected by the change described in Block 13. Enter the affected document number in Block 20 .

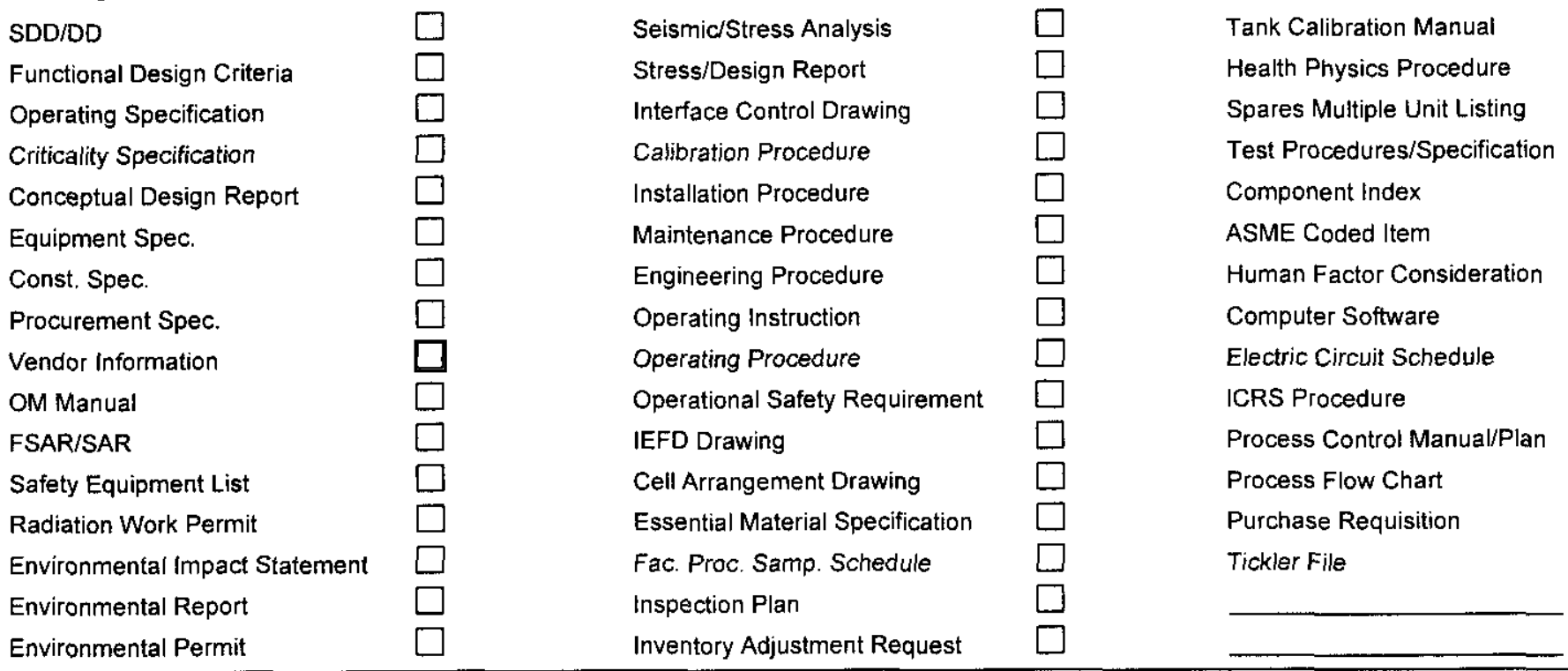

Tank Calibration Manual Health Physics Procedure Spares Multiple Unit Listing fication Conceptual Design Report

$\square$
$\square$
$\square$
$\square$
$\square$
$\square$
$\square$
$\square$
$\square$
$\square$
$\square$
$\square$

20. Other Affected Documents: (NOTE: Documents listed below will not be revised by this ECN.) Signatures below indicate that the signing organization has been notified of other affected documents listed below.

$$
\text { Document Number/Revision Document Number/Revision }
$$

Document Number/Revision

$N / A$

21. Approvals

$$
\text { signatus! }
$$

SOM

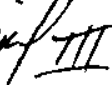
Design Authority C.C. Scajef, III Cog. Eng. D.A. Barnes Daud baume. Cog. Mgr. J.G. Field $4 / 4$ Fielel QA w.L. Adams WKadame Safety x.A. cutforth EA Gotomn



Other $2 / 5 / 00$ $7 / 3 / 00$ $6 / 26 / 00$ $7 / 3 / 00$

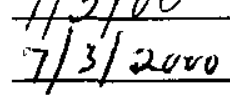

Design Agent

PE

QA

Safety

Design

Environ.

Other

\section{DEPARTMENT OF ENERGY}

Signature or a Control Number that tracks the Approval Signature

\section{ADDITIONAL}




\title{
Tank Monitor and Control System (TMACS) Version Description Document (VDD)
}

\author{
D.A. Barnes \\ CH2M HILL Hanford Group, Inc. \\ Richland, WA 99352 \\ U.S. Department of Energy Contract DE-AC06-99RL14047

$\begin{array}{lll}\text { EDT/ECN: } & \text { ECN-656000 } & \text { UC: } 605 \\ \text { Cost Center: } & 74 \mathrm{~B} 50 & \text { Charge Code: } 102608 \mathrm{~EB} 00 \\ \text { B\&R Code: } & \text { EW3120071 } & \text { Total Pages: } 3 \text { 37-6 Do. }\end{array}$

Key Words: Version Description Document, VDD, TMACS, Tank Monitor and Con trol

Abstract: This document updates the Version Description Document with the changes incorporated in the Revision 12.0 software installation on the Tank Monitor and Control system (TMACS)

TRADEMARK DISCLAIMER. Reference herein to any specific commercial product, process, or service by trade name, trademark, manufacturer, or otherwise, does not necessarily constitute or imply its endorsement, recommendation, or favoring by the United States Government or any agency thereof or its contractors or subcontractors.

Printed in the United States of America. To obtain copies of this document, contact: Document Control Services, P.O. Box 950, Mailstop H6-08, Richland WA 99352, Phone (509) 372-2420; Fax (509) 376-4989.
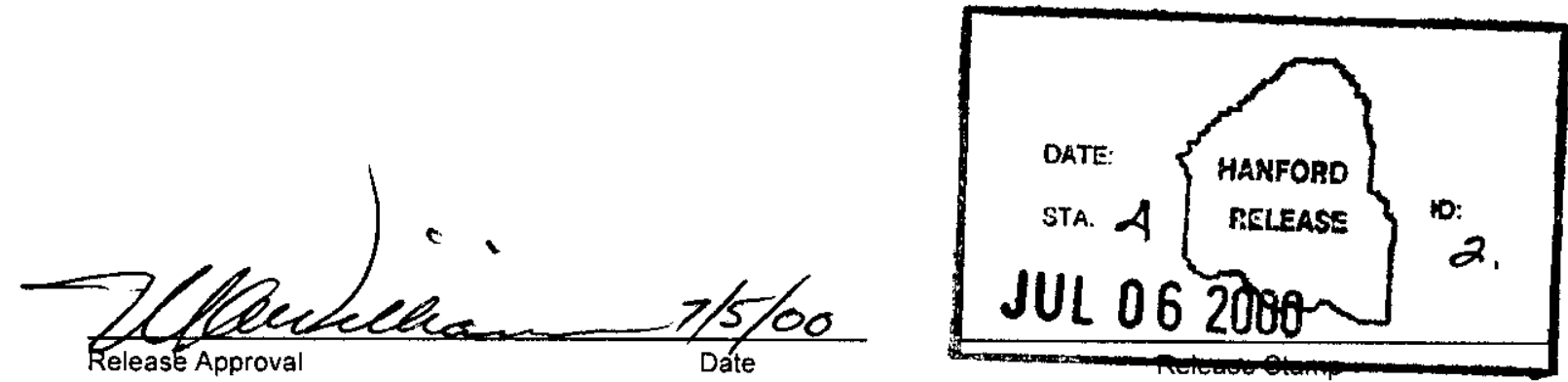

\section{Approved For Public Release}




\section{RECORD OF REVISION}

\section{(1) Document Number}

HNE-3538, Rev 4

Page 1

(2) Title

Tank Monitor and Control System (TMACS) Version Description Document

Change Control Record

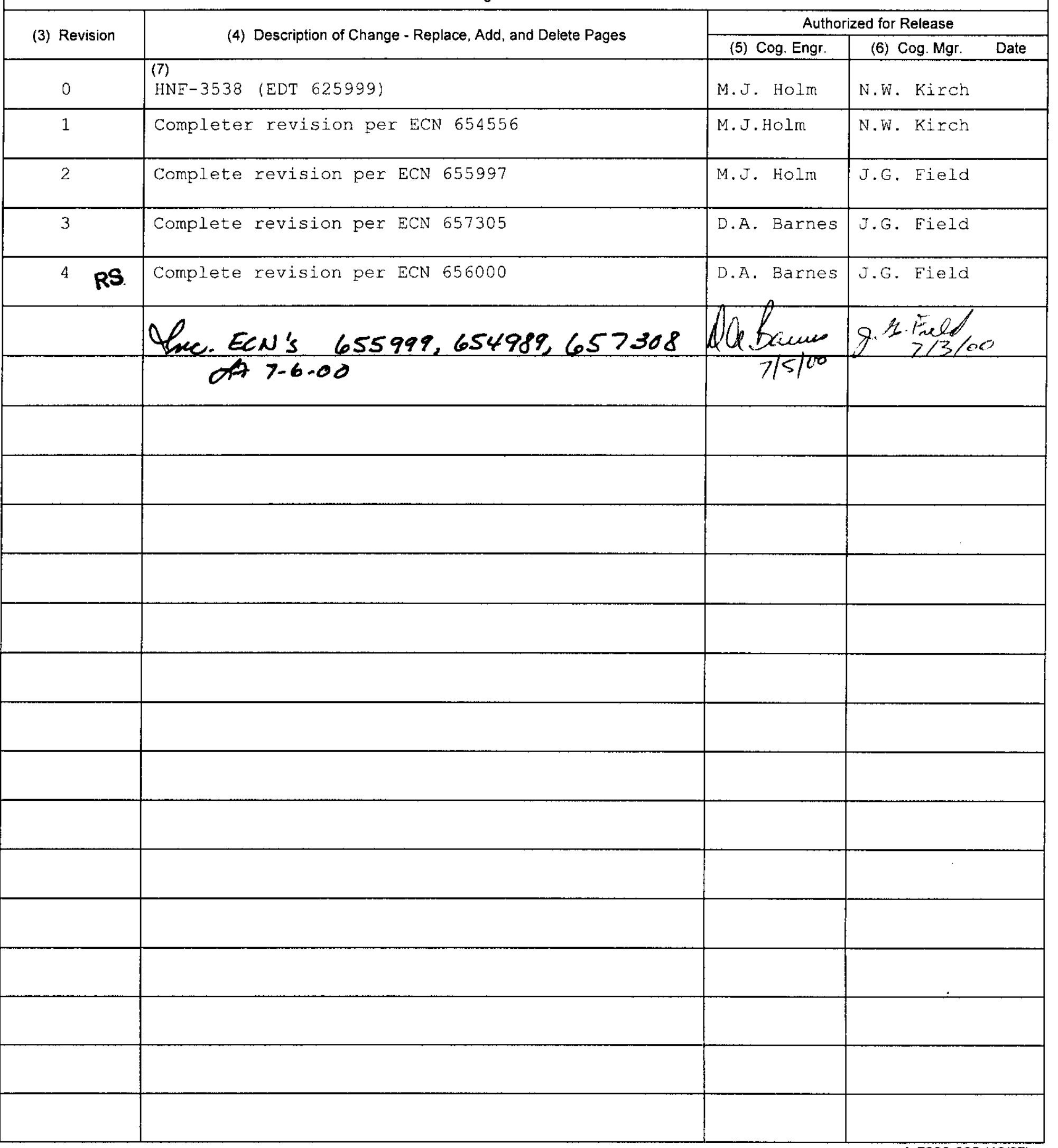


HNF-3538 Rev. 4

\title{
Tank Monitor and Control System (TMACS) Version Description Document
}

\author{
Prepared By \\ Ronald R. Wandling \\ Lockheed Martin Services, Inc.
}

For

CH2M HILL Hanford Group For US Department of Energy Office of River Protection Richland, Washington 


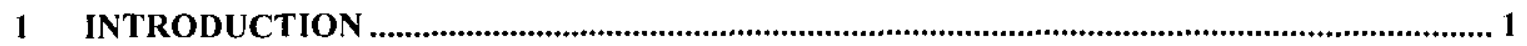

1.1 PURPOSE

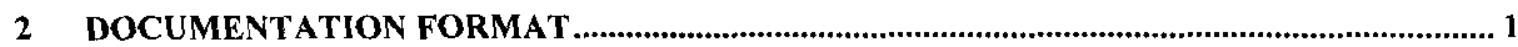

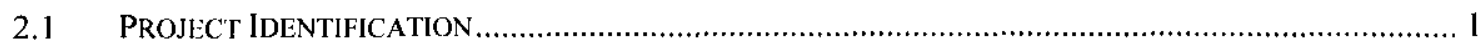

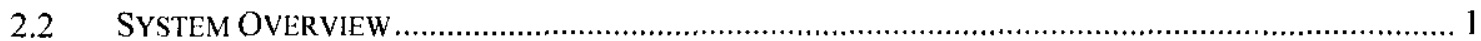

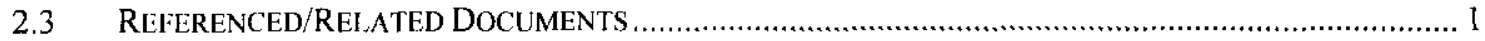

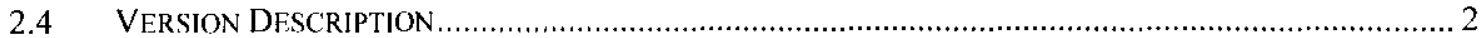

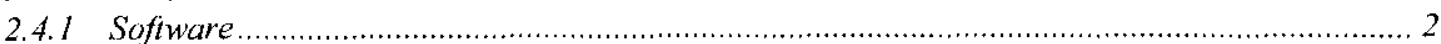

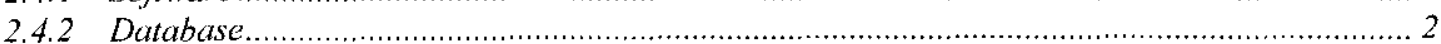

2.4.3 Client Operating System and Environment

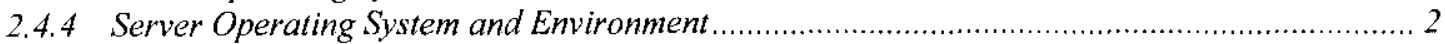

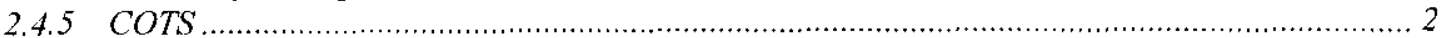

2.4.6 Metadata

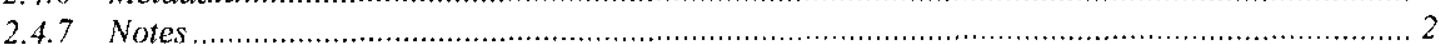

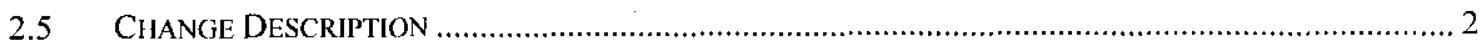



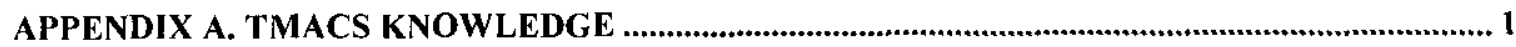

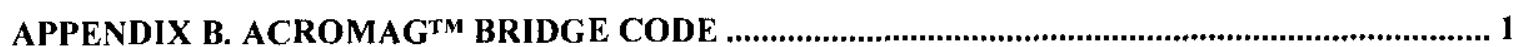

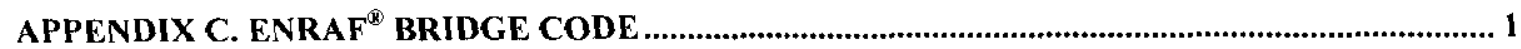

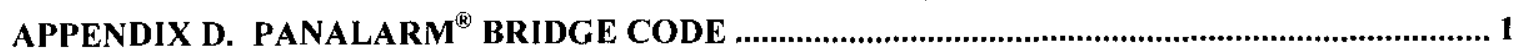

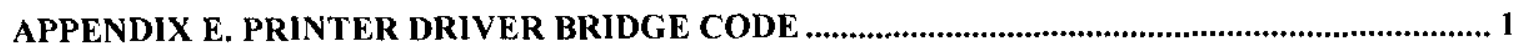

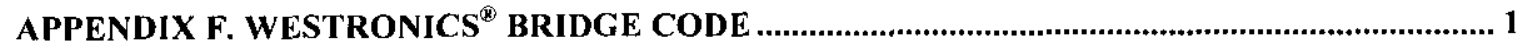

APPENDIX G. WINDOWS NT COMMON CODE................................................................................. 1

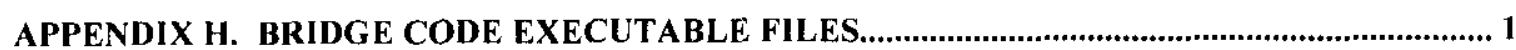




\section{INTRODUCTION}

\subsection{Purpose}

This document contains configuration information for the Tank Monitor and Control System (TMACS) release 12.0. This version was installed in production on June 12 , 2000.

\section{DOCUMENTATION FORMAT}

\subsection{PROJECT IDENTIFICATION}

The Tank Monitor and Control System uses a 3-layer revision descriptor. The descriptor consists of a major revision number, a minor revision number, and a "fix" number, e.g., major revision 5, minor revision 3, and fix 2 would have the identifier 5.3.2.

\subsection{SYSTEM OVERVIEW}

TMACS was established in 1991 under the Tank Farm Instrument Upgrade project to monitor temperatures and surface levels in the Hanford 200 area "watch list" tanks.

\subsection{REFERENCED/RELATED DOCUMENTS}

\begin{tabular}{|l|l|}
\hline System Functional Requirements & WHC-SD-WM-SFR-006, Rev 1 \\
\hline $\begin{array}{l}\text { TMACS As-Built Design } \\
\text { Document }\end{array}$ & WHC-SD-WM-SDD-079, Rev 0 \\
\hline $\begin{array}{l}\text { System Configuration Management } \\
\text { Plan }\end{array}$ & HNF-SD-CSCM-019, Rev 1 \\
\hline $\begin{array}{l}\text { Functional Requirements for the } \\
\text { Acromag I/O Processor Interface } \\
\text { to the Tank Monitor and Control } \\
\text { System (TMACS) }\end{array}$ & HNF-2708, Rev. 0 \\
\hline $\begin{array}{l}\text { Functional Requirements for the } \\
\text { Enraf }{ }^{2} \text { Gauge Interface to the Tank } \\
\text { Monitor and Control System } \\
\text { (TMACS) }\end{array}$ & HNF-2791, Rev. 0 \\
\hline $\begin{array}{l}\text { Functional Requirements for the } \\
\text { Panalarm }{ }^{3} \text { Annunciator System } \\
\text { Interface to the Tank Monitor and } \\
\text { Control System (TMACS) }\end{array}$ & HNF-3053, Rev. 0 \\
\hline $\begin{array}{l}\text { Functional Requirement for the } \\
\text { Westronics }{ }^{4} \text { Interface to the Tank } \\
\begin{array}{l}\text { Monitor and Control System } \\
\text { (TMACS) }\end{array}\end{array}$ & HNF-2607, Rev. 0 \\
\hline
\end{tabular}

\footnotetext{
'Acromag is a trademark of Acromag Incorporated, Wixom, Michigan.

${ }^{2}$ Enraf is a registered trademark of Enraf, B.V.

${ }^{3}$ Panalarm is a registered trademark of Ametek, Inc.

${ }^{4}$ Westronics is a registered trademark of Westronics, Inc.
} 


\subsection{VERSION DESCRIPTION}

\subsubsection{Software}

The main processing performed by TMACS is built using the $\mathrm{G} 2^{5}$ software product from Gensym. The knowledge bases used are in Appendix A.

Interfaces to field equipment use services written in Microsoft ${ }^{6}$ Visual $\mathrm{C}^{7}$. The serial port hardware and software were purchased from Digi ${ }^{8}$ International Incorporated. The source code files are listed in Appendix B through Appendix F. The executable files are listed in Appendix H.

\subsubsection{Database}

None.

2.4.3 Client Operating System and Environment

The client workstations run WindowsNT ${ }^{9}$ workstation 4.0 .

\subsubsection{Server Operating System and Environment}

The WindowsNT ${ }^{\mathrm{TM}}$ server containing the $\mathrm{G} 2^{(}{ }^{\circledR}$ software product from Gensym and the interfaces to field equipment runs WindowsNT ${ }^{\text {TM }}$ Server 4.0 with service pack 3 installed.

\subsubsection{COTS}

Telewindows ${ }^{10}$ Revision 4.0 Release 2 is used for remote display of TMACS. It runs on the client workstations.

$\mathrm{G} 2^{\mathbb{R})}$ Revision 4.1 Release 1 is used to run the main TMACS processing.

\subsubsection{Metadata}

None.

\subsubsection{Notes}

Controlled source files are kept in SourceSafe on the IIUDO computer.

\subsection{Change Description}

The following are the service request incorporated in TMACS revision 12.0

\begin{tabular}{|l|l|}
\hline \hline SR \# & \multicolumn{1}{|c|}{ Abbreviated Description } \\
\hline \hline 455 & Make Unit of Measure for Enrafs consistent \\
\hline 711 & Correct the Acromag remote procedure "Write Digital" \\
\hline
\end{tabular}

${ }^{5} \mathrm{G} 2$ is a registered trademark of the Gensym Corporation.

${ }^{6} \mathrm{Microsoft}$ is a registered trademark of the Microsoft Corporation.

${ }^{7} \mathrm{Visual} \mathrm{C}$ is a trademark of the Microsoft Corporation.

${ }^{8}$ Digi is a trademark of Digi International Incorporated.

${ }^{9}$ WindowsNT is a trademark of Microsoft Corporation.

${ }^{10}$ Telewindows is a registered trademark of the Gensym Corporation. 
HNF-3538 Rev. 4

\begin{tabular}{|l|l|}
\hline \multicolumn{1}{|c|}{ SR \# } & \multicolumn{1}{|c|}{ Abbreviated Description } \\
\hline 878 & Fix Suspect Station IO Report Abort Problem \\
\hline 879 & Fix Reports So The Number Found Matches The Number Displayed \\
\hline 880 & Make Unacknowledge Alarms Stop Blinking when Alarm Processing is Disabled \\
\hline 884 & Fix Remote Procedure Calls So Limit Of 4096 Is Not Reached \\
\hline 885 & Create a function to raise the CIU Enraf displacers on a routine basis \\
\hline 889 & 200 lnch Acromag Conversion Formula \\
\hline 890 & Configure Enraf ClUs For Tank SY101 \\
\hline 891 & Change Instrument Limits for SY103 \\
\hline 892 & Support the transfer of CASS Alarms to TMACS \\
\hline 899 & Move RAWDATA Insert Process onto TMACSPROD \\
\hline 902 & Modify TMACS to insert SACS nightly readings directly. \\
\hline 914 & Change Gauge Address for Enrafs in Tanks AX101 -AX104, AY101 and AY102 \\
\hline 915 & Add Enrafs To Tanks AZ102, AZ151, B101-B112, and B201-B204 \\
\hline 916 & Change Gauge Address for Enraf in Tank AZ101 \\
\hline
\end{tabular}

\subsection{INSTALLATION INSTRUCTION}

TMACS bridges are installed as services on the TMACSPROD server.

The $\mathrm{G} 2{ }^{(1)}$ executable is installed as a program on the TMACSPROD server.

TMACS G $2^{\circledR}$ code is kept in a series of knowledge bases that are transferred to

TMACSPROD for operation.

Telewindows ${ }^{\circledR}$ software is installed on the client workstations and requires a hardware

key. A new version of Telewindows ${ }^{\circledR}$ is installed when a new, vendor-supplied release of $\mathrm{G} 2^{\circledR}$ is installed. 


\section{Appendix A. TMACS Knowledge}

These files are stored in the \$/TMACS/Release Files/11.1/KnowledgeBases directory.

$* * * * * * * * * * * * * * * * * \quad \mathrm{~g} 2$-database. $\mathrm{kb}$

Label: 12.0

User: Steve Date: 6/14/:0 Time: 3:22p

Labeled '12.0'

Label comment:

$* * * * * * * * * * * * * * * * * \mathrm{sys}-\bmod \mathrm{kb} * * * * * * * * * * * * * * * * *$

Label: 12.0

User: Steve

Date: $6 / 14 /: 0$ Time: $3: 22 \mathrm{p}$

Labeled ' 12.0 '

Label comment:

$* * * * * * * * * * * * * * * * *$ uilroot.kb

Label: 12.0

User: Steve

Labeled '12.0'

Date: $6 / 14 /: 0$ Time: $3: 22 p$

Label comment:

$* * * * * * * * * * * * * * * * *$ data-recovery. $\mathrm{kb}$

$* * * * * * * * * * * * * * * * *$

Label: 12.0

User: Steve

Date: 6/14/:0 Time: 3:22p

Labeled ' 12.0 '

Label comment:

$* * * * * * * * * * * * * * * * *$ level. $\mathrm{kb}$

Label: 12.0

User: Steve

Date: $6 / 14 /: 0$ Time: $3: 22 \mathrm{p}$

Labeled '12.0'

Label comment:

$* * * * * * * * * * * * * * * * *$ printer-root. $\mathrm{kb}$

Label: 12.0

User: Steve

Date: $6 / 14 /: 0$ Time: $3: 22 \mathrm{p}$

Labeled '12.0'

Label comment: 
$* * * * * * * * * * * * * * * * *$ surveillance-limit-root.kb

Label: 12.0

User: Steve

Date: $6 / 14 /: 0$ Time: $3: 22 \mathrm{p}$

Labeled ' 12.0 '

Label comment:

$* * * * * * * * * * * * * * * * *$ TMACS_Main.kb

Label: 12.0

User: Steve Date: 6/14/:0 Time: $3: 22 \mathrm{p}$

Labeled '12.0'

Label comment:

$* * * * * * * * * * * * * * * * *$ gensym-raised-buttons.kb

Label: 12.0

User: Steve

Date: $6 / 14 /: 0$ Time: $3: 22 p$

Labeled ' 12.0 '

Label comment:

$* * * * * * * * * * * * * * * * *$ gfi-mod.kb

Label: 12.0

User: Steve

Date: $6 / 14 /: 0$ Time: $3: 22 p$

Labeled '12.0'

Label comment:

Label: 12.0

panalarm-root.kb

User: Steve

Date: $6 / 14 /: 0$ Time: $3: 22 p$

Labeled ' 12.0 '

Label comment:

$* * * * * * * * * * * * * * * * *$ tmacs-definitions. $\mathrm{kb}$

Label: 12.0

User: Steve

Date: $6 / 14 /: 0$ Time: $3: 22 \mathrm{p}$

Labeled ' 12.0 '

Label comment:

$* * * * * * * * * * * * * * * * *$ acromag-root.kb

Label: 12.0

User: Steve

Date: 6/14/:0 Time: 3:22p

Labeled ' 12.0 ' 
Label comment:

$* * * * * * * * * * * * * * * * *$ odbc-root.kb

Label: 12.0

User: Steve

Date: $6 / 14 /: 0$ Time: $3: 22 \mathrm{p}$

Labeled ' 12.0 '

Label comment:

Label: 12.0

User: Steve

Labeled ' $12.0^{\prime}$

Label comment:

$* * * * * * * * * * * * * * * * *$ tmacs-lib.kb

Label: 12.0

User: Steve

Date: $6 / 14 /: 0$ Time: $3: 22 \mathrm{p}$

Labeled '12.0'

Label comment:

$* * * * * * * * * * * * * * * * *$ westronics-root.kb

Label: 12.0

User: Steve

Date: $6 / 14 /: 0$ Time: $3: 22 \mathrm{p}$

Labeled ' 12.0 '

Label comment:

$* * * * * * * * * * * * * * * * *$ enraf-root.kb

Label: 12.0

User: Steve

Date: $6 / 14 /: 0$ Time: $3: 22 p$

Labeled '12.0'

Label comment:

Label: 12.0

User: Steve

Date: $6 / 14 /: 0$ Time: $3: 22 \mathrm{p}$

Labeled ' 12.0 '

Label comment: 


\section{Appendix B. Acromag ${ }^{\mathrm{TM}}$ Bridge Code}

The following is the Microsoft Developer Studio Project File acro_main.dsp that contains the setup and files used to build the Acromag ${ }^{\mathrm{TM}}$ Bridge. The project file and that other files that make up Acromag ${ }^{\mathrm{TM}}$ Bridge are stored in the directory \$/TMACS/Bridges/Acromag directory.

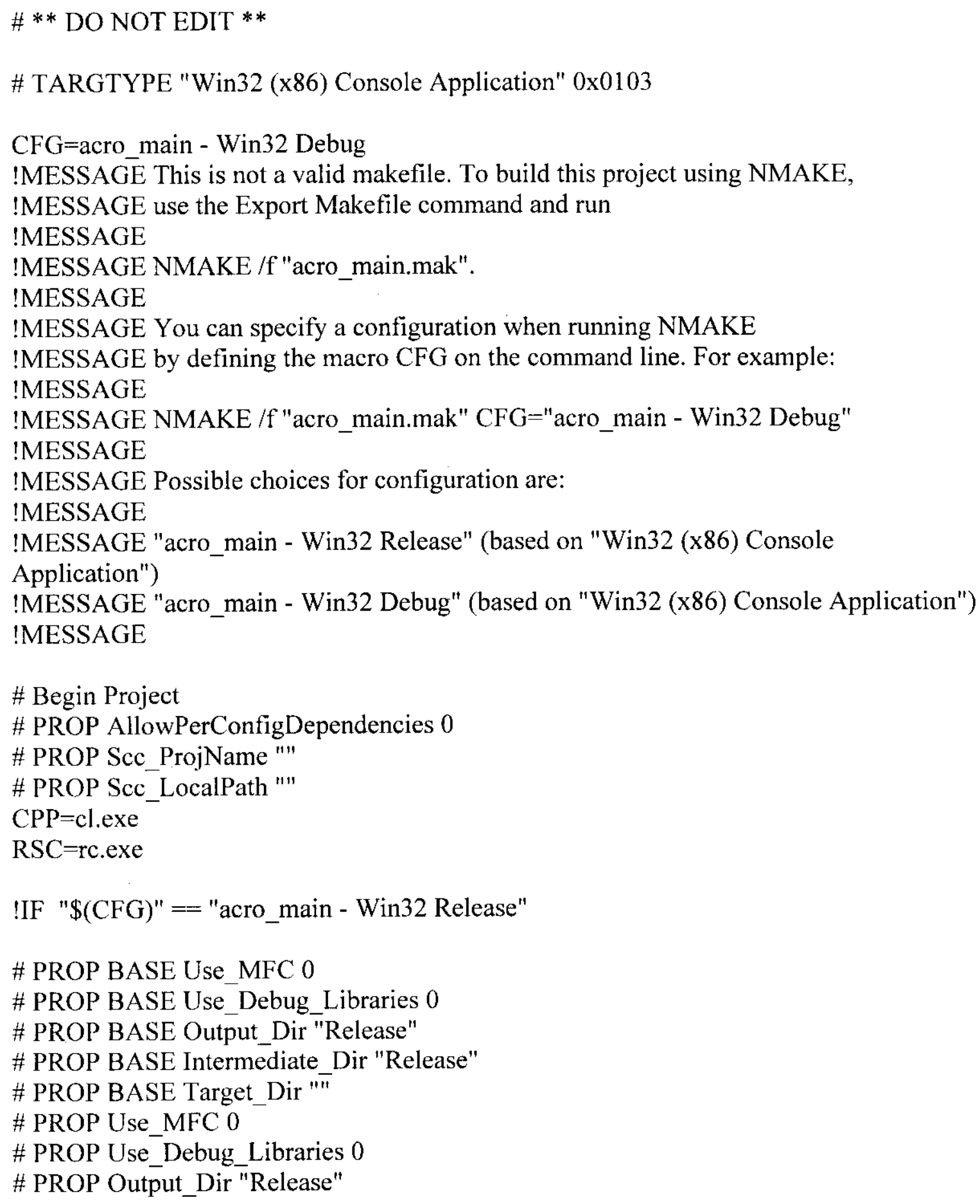







\# ADD BASE LINK32 kernel32.lib user32.lib gdi32.lib winspool.lib comdlg32.lib advapi32.lib shell32.lib ole32.lib oleaut32.lib uuid.lib odbc32.lib odbccp32.lib /nologo /subsystem:console /debug /machine:I386/pdbtype:sept \# ADD LINK32 libgsi.lib libtcp.lib wsock32.lib kernel32.lib user32.lib gdi32.lib winspool.lib comdlg32.lib advapi32.lib shell32.lib ole32.lib oleaut32.lib uuid.lib odbc32.lib odbccp32.lib/nologo /subsystem:console /profile /debug /machine:I386 /nodefaultlib:"libc.lib" /out:"Debug/acromag_drvr.exe" /libpath:"..ggsi32\"

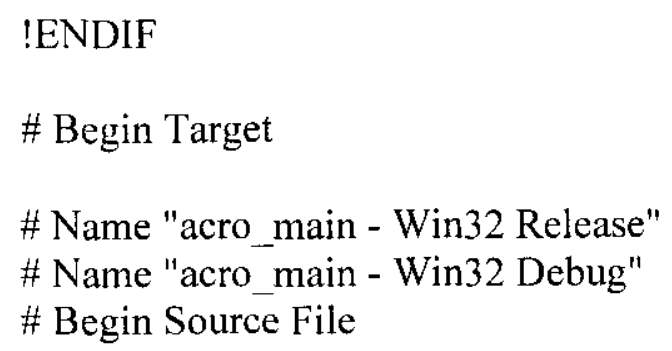


\# Begin Source File

SOURCE $=$. Iservicemain.c

\# End Source File

\# Begin Source File

SOURCE=.।servicemsg.mc

\# End Source File

\# Begin Source File

SOURCE $=$. Iset_check_init.c

\# End Source File

\# Begin Source File

SOURCE=.Iset_physio_nt.c

\# End Source File

\# End Target

\# End Project 


\section{Appendix C. Enraf ${ }^{\text {Bridge Code }}$}

The following is the Microsoft Developer Studio Project File enraf_main.dsp that contains the setup and files used to build the Enraf ${ }^{\circledR}$ Bridge. The project file and that other files that make up Enraf Bridge are stored in the directory

\$/TMACS/Bridges/Enraf directory.

\# Microsoft Developer Studio Project File - Name="enraf_main" - Package Owner $=<4>$ \# Microsoft Developer Studio Generated Build File, Format Version 6.00 \#** DO NOT EDIT

\# TARGTYPE "Win32 (x86) Console Application" 0x0103

$\mathrm{CFG}=$ enraf main - Win32 Debug

!MESSAGE This is not a valid makefile. To build this project using NMAKE, !MESSAGE use the Export Makefile command and run

!MESSAGE

!MESSAGE NMAKE /f "enraf_main.mak".

!MESSAGE

!MESSAGE You can specify a configuration when running NMAKE

!MESSAGE by defining the macro CFG on the command line. For example:

!MESSAGE

!MESSAGE NMAKE /f "enraf_main.mak" CFG="enraf_main - Win32 Debug"

!MESSAGE

!MESSAGE Possible choices for configuration are:

!MESSAGE

!MESSAGE "enraf_main - Win32 Release" (based on "Win32 (x86) Console

Application")

!MESSAGE "enraf_main - Win32 Debug" (based on "Win32 (x86) Console

Application")

!MESSAGE

\# Begin Project

\# PROP AllowPerConfigDependencies 0

\# PROP Scc_ProjName ""

\# PROP Scc_LocalPath "'

$\mathrm{CPP}=\mathrm{cl}$.exe

$\mathrm{RSC}=\mathrm{rc}$.exe

!IF $" \$(C F G) "==$ "enraf_main - Win32 Release"

\# PROP BASE Use_MFC 0

\# PROP BASE Use_Debug_Libraries 0

\# PROP BASE Output_Dir "Release"

\# PROP BASE Intermediate_Dir "Release"

\# PROP BASE Target_Dir "'" 


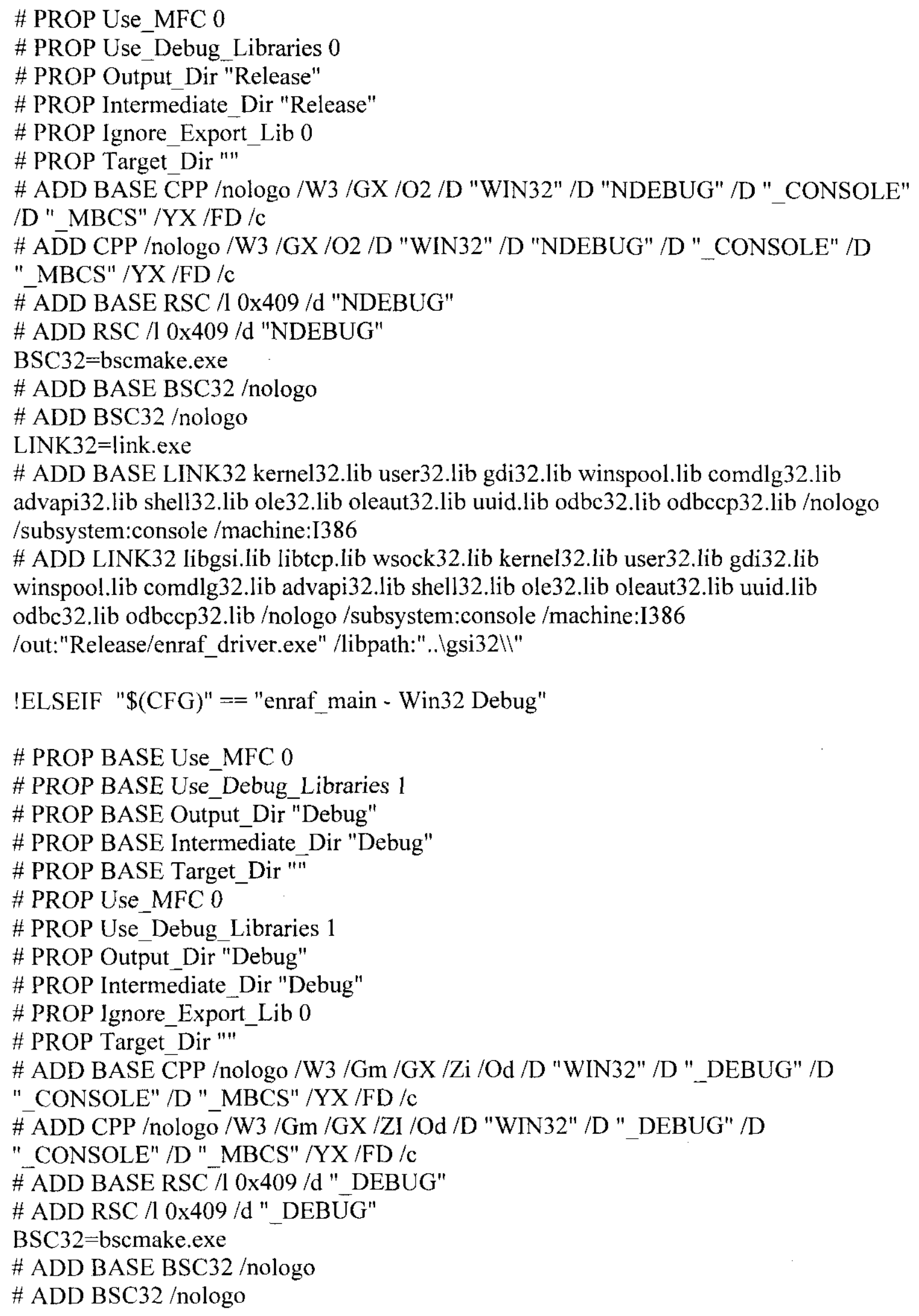


LINK32=link.exe

\# ADD BASE LINK32 kernel32.lib user32.lib gdi32.lib winspool.lib comdlg32.lib advapi32.lib shel132.lib ole32.lib oleaut32.lib uuid.lib odbc32.lib odbccp32.lib /nologo /subsystem:console /debug/machine:I386/pdbtype:sept

\# ADD LINK32 libgsi.lib libtcp.lib wsock32.lib kernel32.lib user32.lib gdi32.lib winspool.lib comdlg32.lib advapi32.lib shell32.lib ole32.lib oleaut32.lib uuid.lib odbc32.lib odbcep32.lib /nologo /subsystem:console /debug /machine:I386 /nodefaultlib:"libc.lib" /out:"Debug/enraf_driver.exe" /pdbtype:sept /libpath:"..Igsi32|l"

!ENDIF

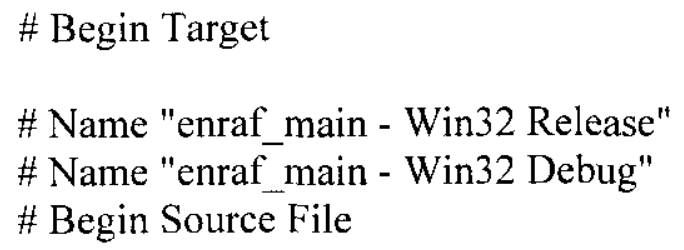


\# End Source File

\# Begin Source File

SOURCE $=$.ISERVICE.C

\# End Source File

\# Begin Source File

SOURCE $=$. Iservicemain.c

\# End Source File

\# Begin Source File

SOURCE $=$. Iservicemsg.mc

\# End Source File

\# Begin Source File

SOURCE $=$. Iset physio nt.c

\# End Source File

\# End Target

\# End Project 


\section{Appendix D. Panalarm ${ }^{\circledR}$ Bridge Code}

The following is the Microsoft Developer Studio Project File gsi_main.dsp that contains the setup and files used to build the Panalarm ${ }^{\mathbb{R}}$ Bridge. The project file and that other files that make up Panalarm ${ }^{(i)}$ Bridge aree stored in the directory $\$ /$ TMACS/Bridges/Panalarm directory.

\$/TMACS/Bridges/Panalarm

\# Microsoft Developer Studio Project File - Name="gsi_main" - Package Owner $=<4>$ \# Microsoft Developer Studio Generated Build File, Format Version 6.00 \#** DO NOT EDIT

\# TARGTYPE "Win32 (x86) Console Application" 0x0103

CFG=gsi_main - Win32 Debug !MESSAGE This is not a valid makefile. To build this project using NMAKE, !MESSAGE use the Export Makefile command and run !MESSAGE

!MESSAGE NMAKE /f "gsi_main.mak".

!MESSAGE

!MESSAGE You can specify a configuration when running NMAKE

!MESSAGE by defining the macro CFG on the command line. For example: !MESSAGE !MESSAGE NMAKE /f "gsi_main.mak" CFG="gsi_main - Win32 Debug" !MESSAGE

!MESSAGE Possible choices for configuration are:

!MESSAGE

!MESSAGE "gsi main - Win32 Release" (based on "Win32 (x86) Console Application") !MESSAGE "gsi_main - Win32 Debug" (based on "Win32 (x86) Console Application") !MESSAGE

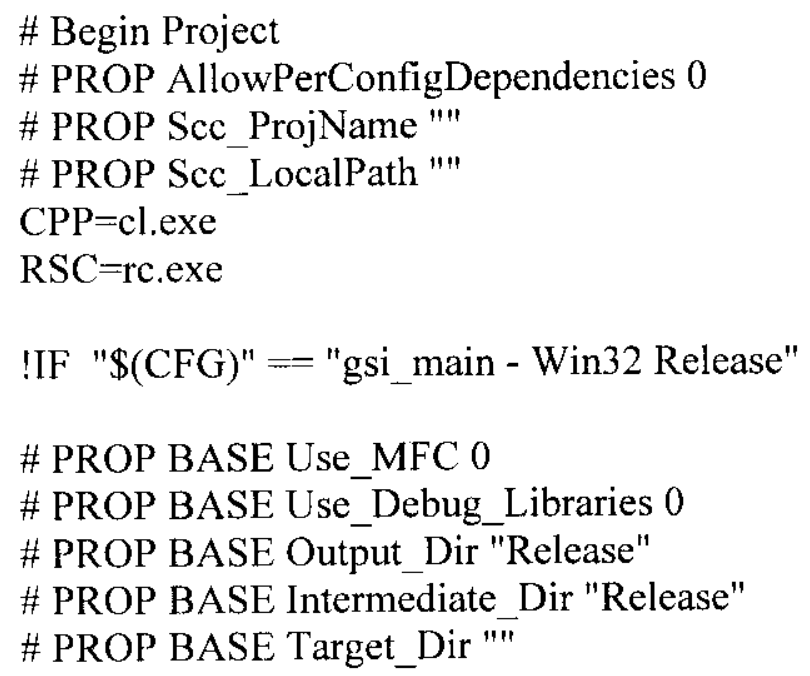




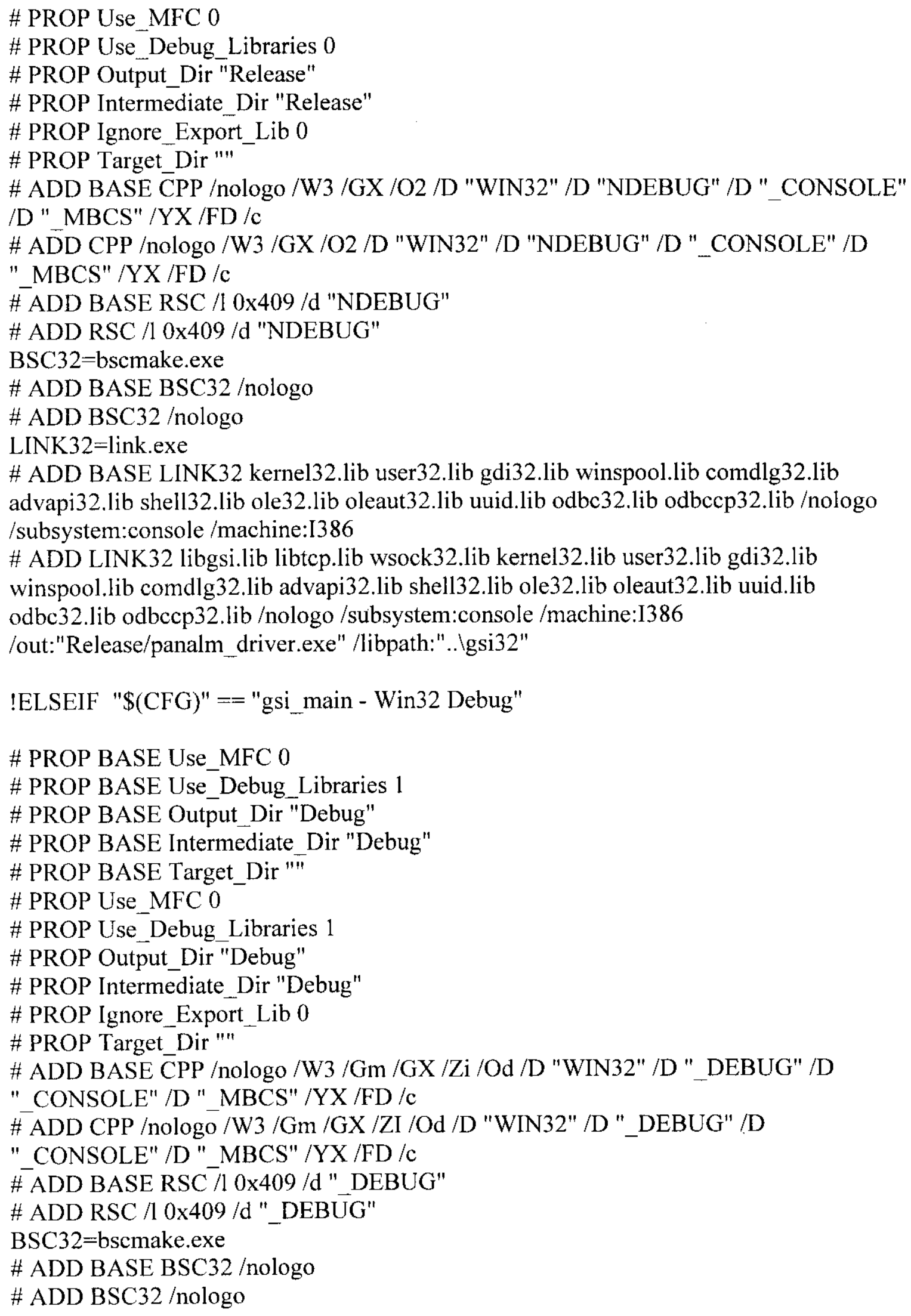


LINK32=link.exe

\# ADD BASE LINK32 kernel32.lib user32.lib gdi32.lib winspool.lib comdlg32.lib advapi32.lib shell32.lib ole32.lib oleaut32.lib uuid.lib odbc32.lib odbccp32.lib / nologo /subsystem:console /debug /machine:I386/pdbtype:sept \# ADD LINK32 libgsi.lib libtcp.lib wsock32.lib kernel32.lib user32.lib gdi32.lib winspool.lib comdlg32.lib advapi32.lib shell32.lib ole32.lib oleaut32.lib uuid.lib odbc32.lib odbccp32.lib /nologo /subsystem:console /debug /machine:I386 /nodefaultlib:"libc.lib" /out:"Debug/panalm_driver.exe" /pdbtype:sept/libpath:"..gssi32"

!ENDIF

\# Begin Target

\# Name "gsi_main - Win32 Release"

\# Name "gsi_main - Win32 Debug"

\# Begin Source File

SOURCE=.Igsi_main.c

\# End Source File

\# Begin Source File

SOURCE=.|gsi_utils.c

\# End Source File

\# Begin Source File

SOURCE $=$. panalarm.rc

\# End Source File

\# Begin Source File

SOURCE $=$. panalm_bridge.c

\# End Source File

\# Begin Source File

SOURCE $=$. panalm_functions.c

\# End Source File

\# Begin Source File

SOURCE $=$. .panalm_link.c

\# End Source File

\# Begin Source File

SOURCE $=. \mid$ panalm_rpc.c

\# End Source File

\# Begin Source File

SOURCE $=. \mid$ panalm_utils.c 
\# End Source File

\# Begin Source File

SOURCE $=$. ISERVICE.C

\# End Source File

\# Begin Source File

SOURCE $=$. Iservicemain.c

\# End Source File

\# Begin Source File

SOURCE=.Iset check_init.c

\# End Source File

\# Begin Source File

SOURCE $=$. Iset physio_nt.c

\# End Source File

\# End Target

\# End Project 


\section{Appendix E. Printer Driver Bridge Code}

The following is the Microsoft Developer Studio Project File printer_main.dsp that contains the setup and files used to build the Printer Bridge. The project file and that other files that make up Printer Bridge are stored in the directory $\$ /$ TMACS/Bridges/Printer directory.

\# Microsoft Developer Studio Project File - Name="printer_main" - Package Owner $=<4>$ \# Microsoft Developer Studio Generated Build File, Format Version 6.00 \#** DO NOT EDIT **

\# TARGTYPE "Win32 (x86) Console Application" 0x0103

$\mathrm{CFG}=$ printer main - Win32 Debug

!MESSAGE This is not a valid makefile. To build this project using NMAKE, !MESSAGE use the Export Makefile command and run

!MESSAGE

!MESSAGE NMAKE /f "printer_main.mak".

!MESSAGE

!MESSAGE You can specify a configuration when running NMAKE

!MESSAGE by defining the macro CFG on the command line. For example:

!MESSAGE

!MESSAGE NMAKE /f "printer_main.mak" CFG="printer_main - Win32 Debug"

!MESSAGE

!MESSAGE Possible choices for configuration are:

!MESSAGE

!MESSAGE "printer_main - Win32 Release" (based on "Win32 (x86) Console Application")

!MESSAGE "printer_main - Win32 Debug" (based on "Win32 (x86) Console

Application")

!MESSAGE

\# Begin Project

\# PROP AllowPerConfigDependencies 0

\# PROP Scc_ProjName ""

\# PROP Scc_LocalPath ""

$\mathrm{CPP}=$ cl.exe

$\mathrm{RSC}=\mathrm{rc} . \mathrm{exe}$

!IF $" \$(C F G) "=$ "printer_main - Win32 Release"

\# PROP BASE Use_MFC 0

\# PROP BASE Use_Debug_Libraries 0

\# PROP BASE Output_Dir "Release"

\# PROP BASE Intermediate Dir "Release"

\# PROP BASE Target_Dir "" 


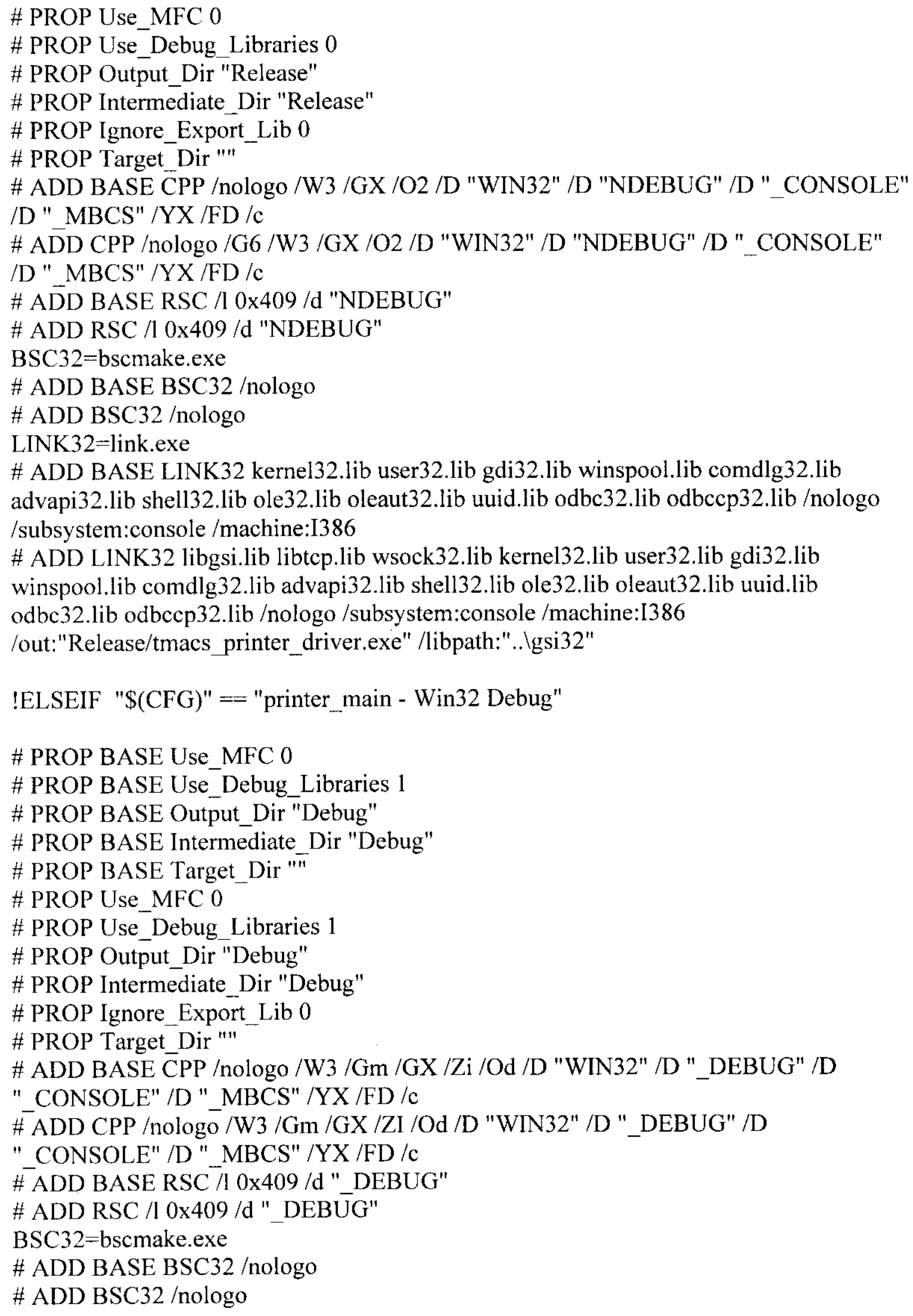


LINK32=link.exe

\# ADD BASE LINK32 kernel32.lib user32.lib gdi32.lib winspool.lib comdlg32.lib advapi32.lib shell32.lib ole32.lib oleaut32.lib uuid.lib odbc32.lib odbccp32.lib /nologo /subsystem:console /debug /machine:I386/pdbtype:sept \# ADD LINK32 libgsi.lib libtcp.lib wsock32.lib kernel32.lib user32.lib gdi32.lib winspool.lib comdlg32.lib advapi32.lib shell32.lib ole32.lib oleaut32.lib uuid.lib odbc32.lib odbccp32.lib/nologo /subsystem:console /debug /machine:I386 /nodefaultlib:"libc.lib" /out:"Debug/tmacs_printer_driver.exe" /pdbtype:sept /libpath:"..Igsi32"

\section{!ENDIF}

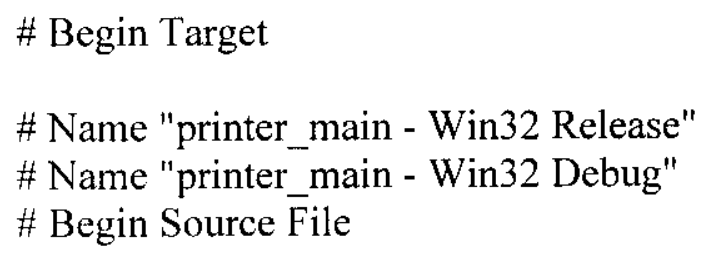




\section{Appendix F. Westronics ${ }^{\circledR}$ Bridge Code}

The following is the Microsoft Developer Studio Project File west_main.dsp that contains the setup and files used to build the Westronics ${ }^{\circledR}$ Bridge. The project file and that other files that make up Westronics ${ }^{\circledR}$ Bridge are stored in the directory

$\$ /$ TMACS/Bridges/Westronics $\mathbb{B}$ directory.

\# Microsoft Developer Studio Project File - Name="west_main" - Package Owner $=<4>$

\# Microsoft Developer Studio Generated Build File, Format Version 6.00

\#** DO NOT EDIT **

\# TARGTYPE "Win32 (x86) Console Application" 0x0103

$\mathrm{CFG}=$ west main - Win32 Debug

!MESSAGE This is not a valid makefile. To build this project using NMAKE,

!MESSAGE use the Export Makefile command and run

!MESSAGE

!MESSAGE NMAKE /f "west_main.mak".

!MESSAGE

!MESSAGE You can specify a configuration when running NMAKE

!MESSAGE by defining the macro CFG on the command line. For example:

!MESSAGE

!MESSAGE NMAKE /f "west_main.mak" CFG="west_main - Win32 Debug"

!MESSAGE

!MESSAGE Possible choices for configuration are:

!MESSAGE

!MESSAGE "west_main - Win32 Release" (based on "Win32 (x86) Console

Application")

!MESSAGE "west_main - Win32 Debug" (based on "Win32 (x86) Console

Application")

!MESSAGE

\# Begin Project

\# PROP AllowPerConfigDependencies 0

\# PROP Scc_ProjName ""

\# PROP Scc LocalPath ""

$\mathrm{CPP}=$ cl.exe

$\mathrm{RSC}=$ rc.exe

!IF $" \$(C F G) "==$ "west_main - Win32 Release"

\# PROP BASE Use_MFC 0

\# PROP BASE Use_Debug_Libraries 0

\# PROP BASE Output_Dir "Release"

\# PROP BASE Intermediate_Dir "Release"

\# PROP BASE Target_Dir ""

\# PROP Use_MFC 0 


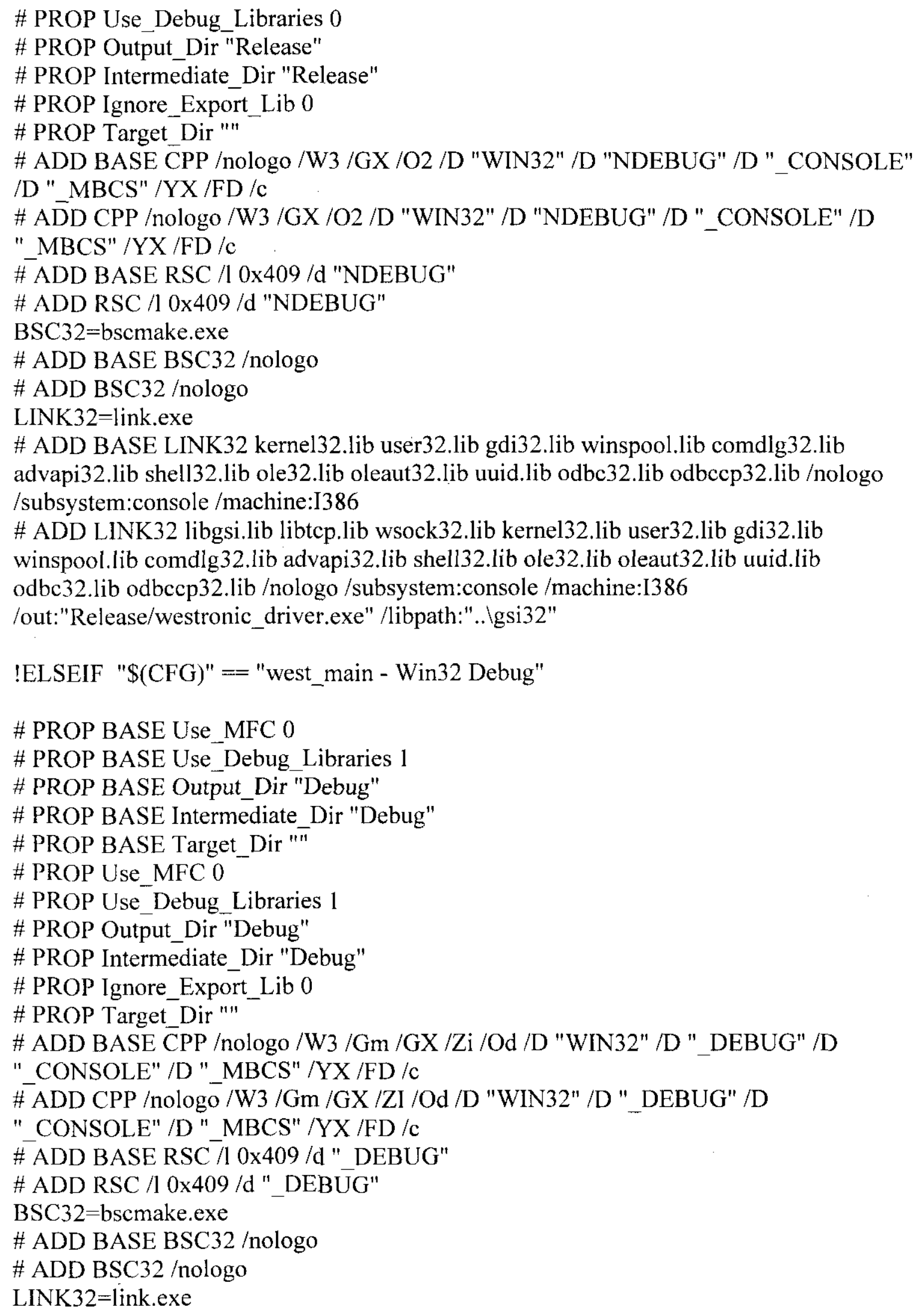


\# ADD BASE LINK32 kernel32.lib user32.lib gdi32.lib winspool.lib comdlg32.lib advapi32.lib shell32.lib ole32.lib oleaut32.lib uuid.lib odbc32.lib odbccp32.lib /nologo /subsystem:console /debug /machine:1386/pdbtype:sept

\# ADD LINK32 libgsi.lib libtcp.lib wsock32.lib kernel32.lib user32.lib gdi32.lib winspool.lib comdlg32.lib advapi32.lib shell32.lib ole32.lib oleaut32.lib uuid.lib odbc32.lib odbccp32.lib /nologo /subsystem:console /debug /machine:I386 /nodefaultlib:"libc.lib" /out:"Debug/westronic_driver.exe" /pdbtype:sept /libpath:"..ggsi32"

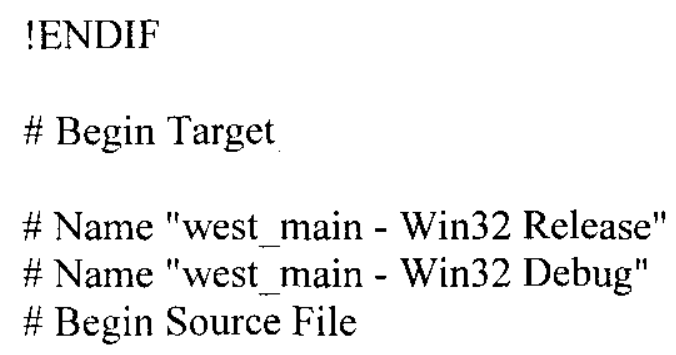

SOURCE=.।set physio_nt.c \# End Source File

\# Begin Source File

SOURCE =. Iwest_bridge.c

\# End Source File

\# Begin Source File

SOURCE $=$. Iwest_link.c 
\# End Source File

\# Begin Source File

SOURCE=.lwest_main.c

\# End Source File

\# Begin Source File

SOURCE=.lwest_rpcs.c

\# End Source File

\# Begin Source File

SOURCE=-Iwestronic.rc

\# End Source File

\# End Target

\# End Project 


\section{Appendix G. Windows NT Common Code}

These Files are stored in the \$/TMACS/Bridges/WinNT Common Code directory.

$* * * * * * * * * * * * * * * * *$ MSG00001.bin

Label: 12.0

User: Steve

Date: $6 / 14 /: 0$ Time: $2: 03 \mathrm{p}$

Labeled ' 12.0 '

Label comment:

Label: 12.0

User: Steve

Labeled ' 12.0 '

Label comment:

$* * * * * * * * * * * * * * * * *$ servicemsg.h

Label: 12.0

User: Steve Date: 6/14/:0 Time: 2:03p

Labeled ' 12.0 '

Label comment:

$* * * * * * * * * * * * * * * * *$ servicemsg.mc

Label: 12.0

User: Steve

Labeled '12.0'

Label comment:

Date: 6/14/:0 Time: 2:03p

Label: 12.0

User: Steve

Labeled '12.0'

Label comment:

Date: 6/14/:0 Time: 2:03p

Label: 12.0

User: Steve

Labeled '12.0'

Label comment: 
HNF-3538 Rev. 4

Label: 12.0

User: Steve

Date: 6/14/:0 Time: 2:03p

Labeled ' 12.0 '

Label comment:

$* * * * * * * * * * * * * * * * *$ set physio nt.c

Label: 12.0

User: Steve

Labeled '12.0'

Date: 6/14/:0 Tíme: 2:03p

Label comment: 


\section{Appendix H. Bridge Code Executable Files}

These files are stored in the \$/TMACS/Release Files/12.0/Bridge Executables directory.

$* * * * * * * * * * * * * * * *$ enraf_driver.exe

Label: 12.0

User: Steve

Date: 6/14/:0 Time: $3: 22 p$

Labeled ' 12.0 '

Label comment:

$* * * * * * * * * * * * * * * * *$ panalm_driver.exe

Label: 12.0

User: Steve

Date: $6 / 14 /: 0$ Time: $3: 22 \mathrm{p}$

Labeled ' 12.0 '

Label comment:

$* * * * * * * * * * * * * * * * *$ tmacs_printer_driver.exe

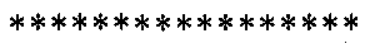

Label: 12.0

User: Steve

Date: $6 / 14 /: 0$ Time: $3: 22 p$

Labeled '12.0'

Label comment:

$* * * * * * * * * * * * * * * * *$ westronic_driver.exe

Label: 12.0

User: Steve

Date: $6 / 14 /: 0$ Time: $3: 22 \mathrm{p}$

Labeled ' 12.0 '

Label comment:

$* * * * * * * * * * * * * * * * *$ acromag_driver.exe

Label: 12.0

User: Steve

Date: $6 / 14 /: 0$ Time: $3: 22 \mathrm{p}$

Labeled ' 12.0 '

Label comment: 
DISTRIBUTION SHEET

To

Distribution

Project Title/Work Order

Tank Monitor and Control System (TMACS) Version Description Document
From

Data Development \& Interpretation

ED
Page 1 of 1

Date $6 / 22 / 2000$

EDT No.

ECN No. 656000

\begin{tabular}{|c|c|c|c|c|c|}
\hline Name & MSIN & $\begin{array}{c}\text { Text } \\
\text { With All } \\
\text { Attach. }\end{array}$ & Text Only & $\begin{array}{l}\text { Attach.I } \\
\text { Appendix } \\
\text { Only }\end{array}$ & $\begin{array}{c}\text { EDT/ECN } \\
\text { Only }\end{array}$ \\
\hline & $R 2-12$ & $x$ & & & \\
\hline & S5-07 & $x$ & & & \\
\hline & $\mathrm{R} 1-01$ & $x$ & & & \\
\hline & $R 2-33$ & $x$ & & & \\
\hline & $\mathrm{R} 2-12$ & $x$ & & & \\
\hline & $56-15$ & $\dot{x}$ & & & \\
\hline & $55-07$ & $x$ & & & \\
\hline & $R I-51$ & $x$ & & & \\
\hline & $R 3-83$ & $\mathrm{x}$ & & & \\
\hline & $H 8-43$ & $\mathrm{x}$ & & & \\
\hline & $\mathrm{R} I-01$ & $x$ & & & \\
\hline & $\mathrm{H} 8-43$ & $\mathrm{x}$ & & & \\
\hline & $R 2-12$ & $x$ & & & \\
\hline & $B 1-07$ & $x$ & & & \\
\hline & & & & & \\
\hline & & & & & \\
\hline & & & & & \\
\hline & & & & & \\
\hline & & & & & \\
\hline & & & & & \\
\hline & & & & & \\
\hline & & & & & \\
\hline & & & & & \\
\hline & & & & & \\
\hline & & & & & \\
\hline & & & & & \\
\hline & & & & & \\
\hline & & & & & \\
\hline & & & & & \\
\hline & & & & & \\
\hline
\end{tabular}

D.A. Barnes

J.S. Bryce

S.C. Cantrell

T. Erickson

J.G. Field

W.A. Adams

W. J. Kennedy

P.G. Miller

C.C. Scaief, III

P.L. Smith

R.R. Wandling

D.D. Scott

D.T. Heimberger

Central Files 